\title{
QUANTITATIVE MODELING OF THE WATER FOOTPRINT AND ENERGY CONTENT OF CROP AND ANIMAL PRODUCTS CONSUMPTION IN TANZANIA
}

\author{
Felichesmi Selestini Lyakurwa \\ Mzumbe University, United Republic Of Tanzania \\ E-mail: fslyakurwa@mzumbe.ac.tz \\ lyakurwa@mail.dlut.edu.cn
}

Submission: 05/12/2013

Revision: 12/12/2013

\section{ABSTRACT}

Accept: 18/12/2013

A comprehensive understanding of the link between water footprint and energy content of crop and animal products is vitally important for the sound management of water resources. In this study, I developed a mathematical relationship between water content, and energy content of many crops and animal products by using an improved LCA approach (i.e., water footprint concept). The standard values of the water and energy content of crops and animal products were obtained from the databases of Agricultural Research Service, UNESCO Institute for water education and Food, and Agriculture Organization of the United Nations. The water footprint approach was applied to analyze the relationship between water requirement and the energy of content of crop and animal products, in which the uncertainty and sensitivity was evaluated by Monte Carlo simulation technique that is contained in the Oracle Crystal Ball Fusion Edition v11.1.1.3.00. The results revealed significant water saving due to changes in food consumption pattern (i.e., from consumption of more meat than vegetables). The production of $1 \mathrm{kcal}$ of crop and animal products requires about $98 \%$ of green, $4.8 \%$ blue water and $0.4 \%$ of gray water. In which changes in consumption pattern gave annual blue water saving of about $1605 \mathrm{Mm}^{3}$ that is equivalent to $41.30 \mathrm{~m}^{3} /$ capita, extremely greater than the standard drinking water requirement for the whole population. Moreover, the projected results indicated, triple increase of dietary water requirement from $30.9 \mathrm{Mm}^{3}$ in 2005 to 108 
INDEPENDENT JOURNAL OF MANAGEMENT \& PRODUCTION (IJM\&P)

http://www.ijmp.jor.br

v. 5, n. 2, February - May 2014.

ISSN: 2236-269X

DOI: 10.14807/ijmp.v5i2.176

$\mathrm{Mm}^{3}$ by 2050 . It was also inferred that, Tanzania has a positive virtual water balance of crop and animal products consumption with net virtual water import of $9.1 \mathrm{Mm}^{3}$ that is the contribution margin to the water scarcity alleviation strategy. Therefore, this relationship of water footprint and energy content of crops and animal products can be used by water resource experts for sustainable freshwater and food supply.

Keywords: Water footprint, energy content, human health, crop, animal products

\section{INTRODUCTION}

A large quantity of crop and animal products whose production process contributes greatly to the global climate change and freshwater scarcity are produced and consumed daily (CLEVELAND, et al., 2011; VANHAM, et al., 2013; LAM, et al., 2013). The introduction of various agriculture methods including the application of pesticides and herbicides as well as the large consumption of energy intensive food staffs contributes greatly to the current environmental degradations (MUELLER, et al., 2012; GAN, et al., 2012; REEMTSMA, et al., 2013).

Agricultural production contributes about $85 \%$ of the global freshwater use and the amount of water consumption is projected to double by 2050 (PFISTER, et al., 2011). With the increased freshwater consumption, the world is placed at risk of climate change which is the global issue of environmental concern resulting in the possible deterioration of human health and quality of ecosystems (BOULAY, et al., 2011; HELLER; KEOLEIAN, 2011; KOEHLER, 2008).

Likewise, significant environmental impacts that are resultant from the animal production have been realized in many parts of the world. For example livestock raised for meat production in the U.S. contributes to $8 \%$ of global freshwater consumption and global green-house gas production of about $18 \%$ which the numbers are expected to double by 2050 (TUOMISTO; MATTOS, 2011; FAO, 2006).

Considering the environmental impacts of agricultural production, hence developing a precise link between water requirements and energy content of crop and animal products is vitally important. Among various life cycle assessment (LCA) approaches, the water footprint approach is widely applied to the assessment of water content of crop and animal products (BOULAY, et al., 2011; JIAO, et al., 2013). 
Water footprint analysis is the most advanced LCA concept which characterizes freshwater requirements throughout the product life cycle stages (ZHAO, et al., 2010; STOESSEL, et al., 2012; NÚÑEZ, et al., 2013). In LCA studies more emphasis is given to the characterization of environmental impacts that resulted from freshwater unavailability, while little emphasis is given to the estimation of freshwater requirements (BOULAY, et al., 2011; RIDOUTT; PFISTER, 2010; PFISTER, et al., 2009).

With regard to the sustainable consumption of food products, water footprint studies are booming for the fruits and vegetables (STOESSEL et al. 2012), agriculture products (CAZCARRO, et al., 2012; HELLER, et al., 2013), corn grain, stover, wheat straw and soybeans (CHIU; WU, 2012), agriculture and industrial products (HOEKSTRA; MEKONNEN, 2012; CHICO et al. 2013), roses, carnation, alstroemeria, lisianthus, statice and cut foliage flowers (MEKONNEN, et al., 2012) and animal products (TUOMISTO; MATTOS 2011).

However, no regard is given so far to assess the connection between water footprint and energy content of the crop and animal products. Usually freshwater consumption is computed by using the water GAP2 global model or the methodology that was proposed by Hoekstra et al. (BOULAY, et al., 2011; PFISTER, et al., 2011; TUOMISTO; MATTOS, 2011; PFISTER, et al., 2009; HOEKSTRA, et al., 2009).

The former involves costive software which may be only relevant for global studies while the latter is time consuming and is subject to many approximations which are caused by limitations of data. Therefore, this study utilized the scientific experimental data for gray, green and blue water footprints of crop and animal products, which was developed by Makonnen and Hoekstra further followed the methodology proposed by Hoekstra et al. in the computation of the water footprint of crop and animal products consumption (MEKONNEN; HOEKSTRA, 2010). Food energy is the most essential nutrient for the maintenance of human health (POPKIN, et al., 2010; PREMA, 2013).

Moreover, freshwater requirements and human health have varied relationships including water required for drinking, hygiene and food energy production (MOE; RHEINGANS, 2006; SAWKA, et al., 2005; GLEICK, 1996). It is important for policy makers to understand the association between food energy and 
freshwater requirements from the aspect of human health and effective implementation of the integrated water resources management. With integrated water resource management the contradiction between water requirements and supply can be resolved (ROY, et al., 2012; WUTICH, et al., 2012, LIU, et al., 2013).

Tanzania as with other developing countries around the world, and the case for this study is experiencing freshwater scarcity while agricultural production is contributing about $70 \%$ of the national freshwater consumption (NBS, 2012; PACHPUTE, 2010; MAKURIRA, et al., 2009; MUTIRO, et al., 2006). The government of Tanzania is making great efforts to ensure a sustainable supply of food and water including implementation of a virtual water strategy (YANG, et al., 2012; HOEKSTRA; MEKONNEN, 2011; ZHAO, et al., 2010; URT, 1992).

These efforts evoked questions as to what extent do developing countries including Tanzania have benefited from the strategy, and how do changes in food consumption pattern affect water scarcity? These questions are important to the country's policy evaluation. Therefore, the objectives of the present study are to, (1) quantify minimum food energy and drinking water requirements for the healthy population in the country (2) assess the water footprint and energy content of the crop and animal products consumption (3) to model scenarios for the water footprint and energy change due to variations in consumption patterns and (4) determine virtual water transfers from the crop and animal products consumption in Tanzania.

\section{MATERIALS AND METHODS}

\subsection{Approach}

This study has examined the association between blue, green and gray water footprints in relation with the energy content of crop and animal products consumption in Tanzania. Water footprints analysis, blue, green and gray water requirements for the production of crop and animal products were quantified. Blue water is defined as the volume of water the ground and surface water bodies available for abstraction, green water is the volume of water evaporation from the soil while gray water refers to the volume of water needed to dilute pollutants which are released into a natural water body (HOEKSTRA; MEKONNEN, 2012; BERGER, et al., 2012; BAYART, et al., 2010). 
In the present study, the gray and green water footprints were not involved in the scenario analysis and determination of the virtual water transfers since they have no significant contribution to the environmental impacts from freshwater consumption (RIDOUTT; PFISTER, 2010; PFISTER, et al., 2009; CANALS, et al., 2009). Therefore, this study utilized blue water to explore the link between freshwater and energy requirements in the context of freshwater scarcity.

\subsubsection{Water footprint and energy value connection}

Water footprint analysis method was used to evaluate the water footprint of crop and animal products consumption in Tanzania. The energy value and water footprint of crop (340) and animal (145) products were computed based on the experimental data published by the U.S. Agricultural Research Service, UNESCO Institute for water education and Food and Agriculture Organization of the United Nations (FAO, 2012; USDA, 2011; MEKONNEN; HOEKSTRA, 2010).

The uncertainty between water footprint and energy content of crop and animal products was considered by Monte Carlos' simulation performed in the Oracle Crystal Ball Fusion Edition v11.1.1.3.00. The food energy value and water footprint of crop and animal products consumption is presented by Equation 1 and 2 .

$$
\begin{aligned}
E_{c}^{f} & =\sum_{i=1}^{n}\left(Q_{i} \times \varepsilon_{i}\right) \\
W_{c}^{f} & =\sum_{i=1}^{n}\left(Q_{i} \times \omega_{i}\right)
\end{aligned}
$$

Where $E_{c}^{f}$ represents total food (Gcal), $W_{c}^{f}$ presents water footprint of products $\left(\mathrm{Mm}^{3}\right), Q$ is the quantity of products $(\mathrm{Mkg}), \varepsilon$ is energy content of the products $(\mathrm{kcal} / \mathrm{kg}), \omega$ is the water content of products $\left(\mathrm{m}^{3} / \mathrm{kg}\right), i$ is the product type and $n$ is the number of products.

\subsubsection{Water footprint and energy value scenario analysis}

Household changes in consumption of the crop and animal products have significant reduction of water and carbon footprint (RIDOUTT, et al., 2012; STOESSEL, et al., 2012; CAZCARRO, et al., 2012).

The scenario analysis was performed to model water footprint and energy change resulted from the variations in consumption pattern of crop and animal 
products. Crop and animal products (485) consumed in Tanzania were grouped into seven classes including cereals, vegetable and melons, fruits and nuts, oil seed crops, beverage and other crops, and meat, milk and eggs according to the products' energy content and the corresponding water footprint. Four strategically selected percentage values were selected to test best policy options for implementation based on freshwater saving and conservation of minimum food energy requirements (Figure 1).
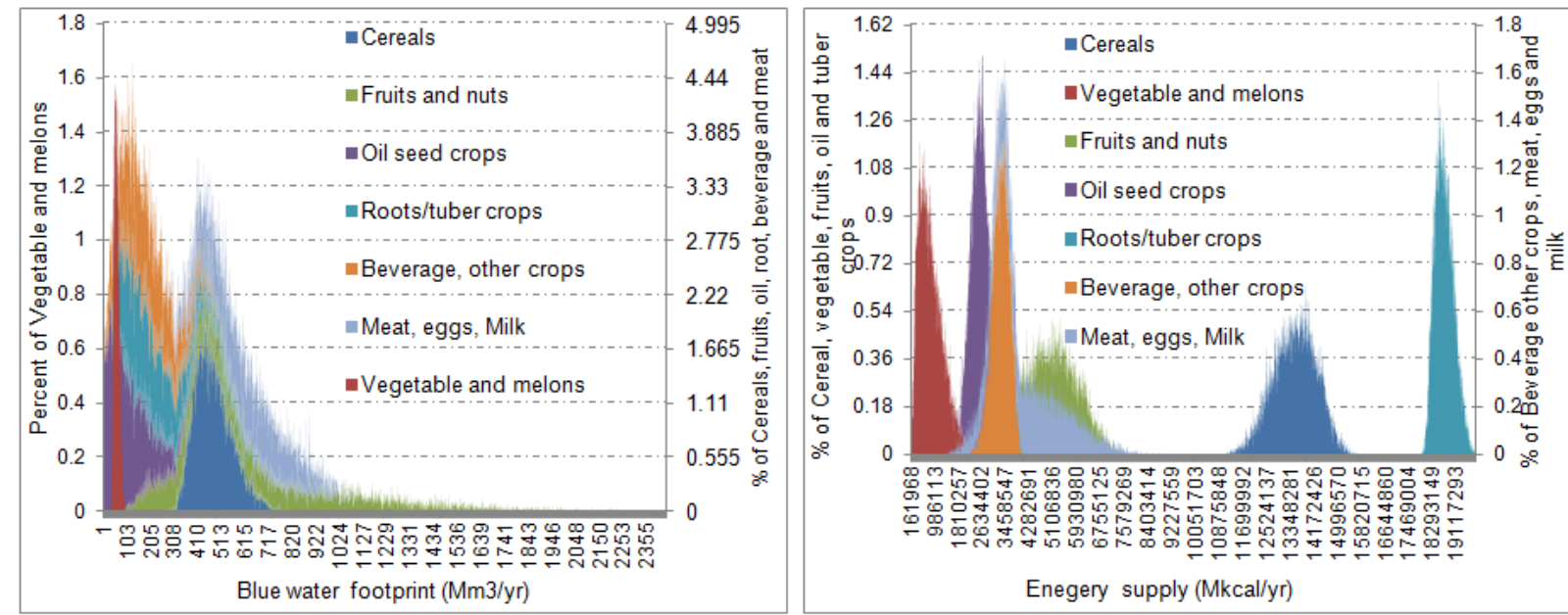

Figure 1: Water footprint and food energy of crop and animal products

\subsubsection{Virtual water transfers of crop and animal products}

The knowledge about water footprint and virtual water strategy is vital for effective implementation of the national water policy. Whereby, water footprint refers to the water embodied into the products while virtual water is the volume of freshwater that is used to produce goods and services consumed by inhabitants of certain area (YANG, et al., 2012; ZHAO, et al., 2010).

The blue, virtual water transfers of Tanzania for 2005 was computed based on the export and import data of crop and animal products provided by FAO food balance sheet and experimental data for blue, gray and green water footprint provided by UNESCO Institute for water education (FAO, 2012; MEKONNEN; HOEKSTRA, 2010). Net-virtual water import is given by Equation 3.

$$
W_{v}^{f}=\sum_{i=1}^{n}\left(Q_{i m p} \times \omega_{i}\right)-\sum_{i=1}^{n}\left(Q_{\text {exp }} \times \omega_{i}\right)
$$


Where $W_{v}^{f}$ represents net virtual transfers of the product $\left(\mathrm{Mm}^{3}\right), Q$ is products import and export (Mkg), $\omega$ is water footprint of the product $\left(\mathrm{m}^{3} / \mathrm{kg}\right)$ and $\mathrm{i}$ is the product type.

\subsubsection{Dietary water and food energy requirement}

All people have equal rights of access to safe drinking water and food in a quantity that meet their basic needs despite of the ages, development and economic situations (SAWKA, et al., 2005).

According to WHO (2012) about 605 million people in the world is expected to live without access to safe drinking water in 2015 accompanied by millions of people at risk of suffering from water related diseases. For Tanzanian, the total drinking water and food energy requirements in 2005 and projections for 2050 for healthy population was modeled using standardized data by World Health Organization and the population pyramid of Tanzania (POPKIN, et al., 2010; U.S. CENSUS BUREAU, 2003; FAO, 2001).

The drinking water and food energy requirements are given by Equation 4 and 5.

$$
\begin{aligned}
W_{r}^{d} & =\sum_{i=1}^{m}\left(p_{i} \times \omega_{i}\right)+\sum_{j=1}^{f}\left(p_{i} \times \omega_{i}\right) \\
E_{r}^{f} & =\sum_{i}^{n}\left(p_{i} \times \varepsilon_{i}\right)+\sum_{i=1}^{f}\left(p_{i} \times \varepsilon_{i}\right)
\end{aligned}
$$

Where $W_{r}^{d}$ and $E_{r}^{f}$ are the drinking water requirement $\left(\mathrm{Mm}^{3}\right)$ and total food energy requirements (Gcal), $p$ represents population (M), $\omega$ is the standard drinking water requirement $\left(\mathrm{m}^{3}\right), \quad \varepsilon$ is standard food energy requirement (kcal), $m$ \& $f$ represents male and female, $i, j$ are ages $\left(0,1,2,3, \ldots \ldots .80^{+}\right.$years $)$.

\section{RESULTS}

\subsection{Water footprint and energy value connection}

The energy supply of crops and animal products consumption in Tanzania is determined by availability of green water than the blue and gray water. A kilocalorie of the product consumption is produced by $98.8 \%$ of green water, $4.8 \%$ blue water and $0.4 \%$ of gray water. The energy intensity of the blue water used for crop and 
animal products was found to be $28055 \mathrm{kcal} / \mathrm{m}^{3}$ for cereals, $14433 \mathrm{kcal} / \mathrm{m}^{3}$ for vegetable and melons $7102 \mathrm{kcal} / \mathrm{m}^{3}$ for fruits and nuts, $21149 \mathrm{kcal} / \mathrm{m}^{3}$ for oil seed crops, $79365 \mathrm{kcal} / \mathrm{m}^{3}$ for root/tuber crops, $16693 \mathrm{kcal} / \mathrm{m}^{3}$ for beverage and other crops, $6973 \mathrm{kcal} / \mathrm{m}^{3}$ for meat, eggs and milk (Figure 2).

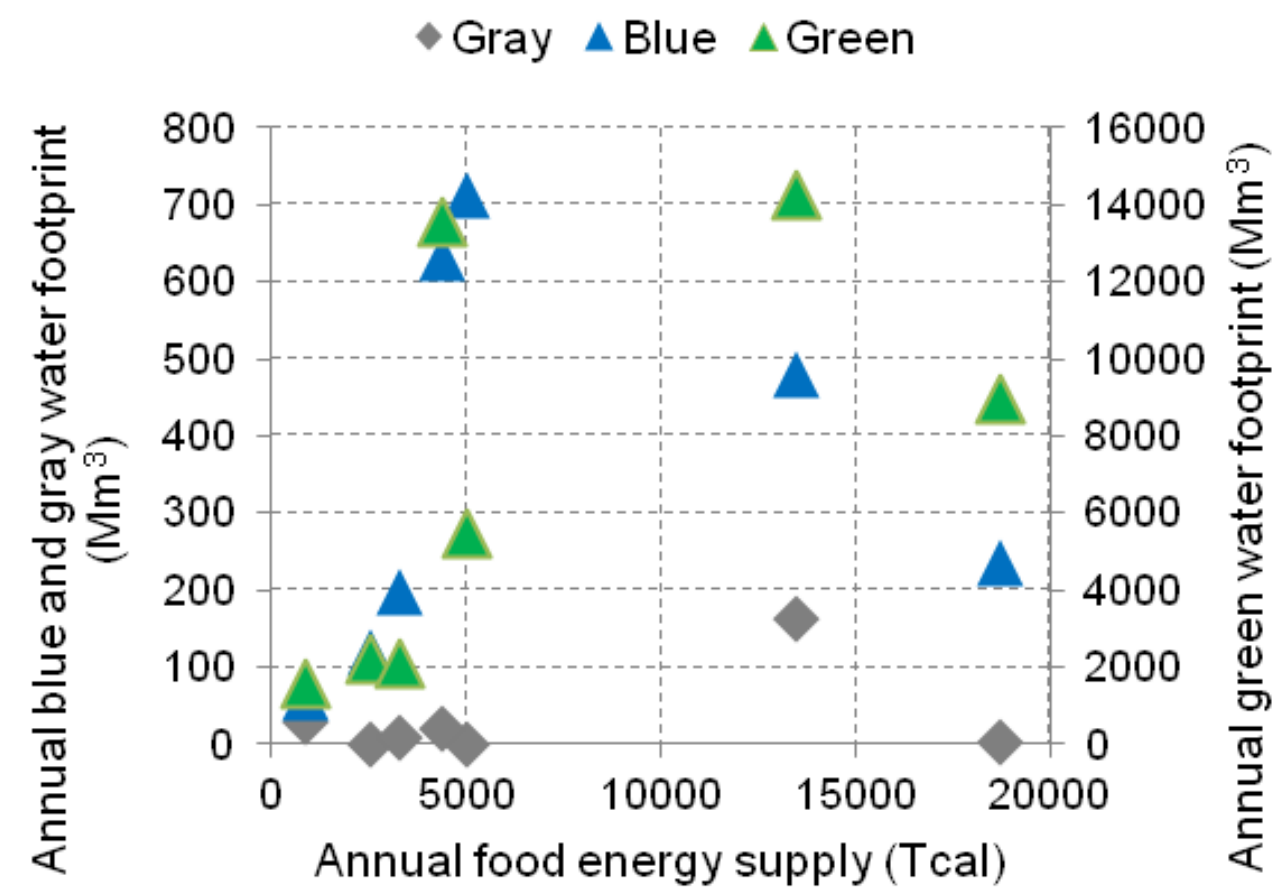

Figure 2: Blue, Green and gray water footprint of food and their energy value

Figure 2 above represent three water types i.e. blue, green and gray which are essential for generation of the unit value of food energy.

\subsection{Drinking water and food energy requirement}

Further environmental impacts especially on human health are expected due to triple increase of freshwater and food energy requirement in Tanzania by 2050 (Figure 3). Dietary drinking water requirements are predicted to be $108 \mathrm{Mm}^{3}$ by 2050 compared to $30.9 \mathrm{Mm}^{3}$ in 2005 , while energy requirement expected to be 91566 Tcal by 2050 compared to 27903 Tcal in 2005 . This study also realized food energy supply by crop and animal products to be relatively higher than required food energy in Tanzania though the country is experiencing water and food insecurity (Figure 3). 

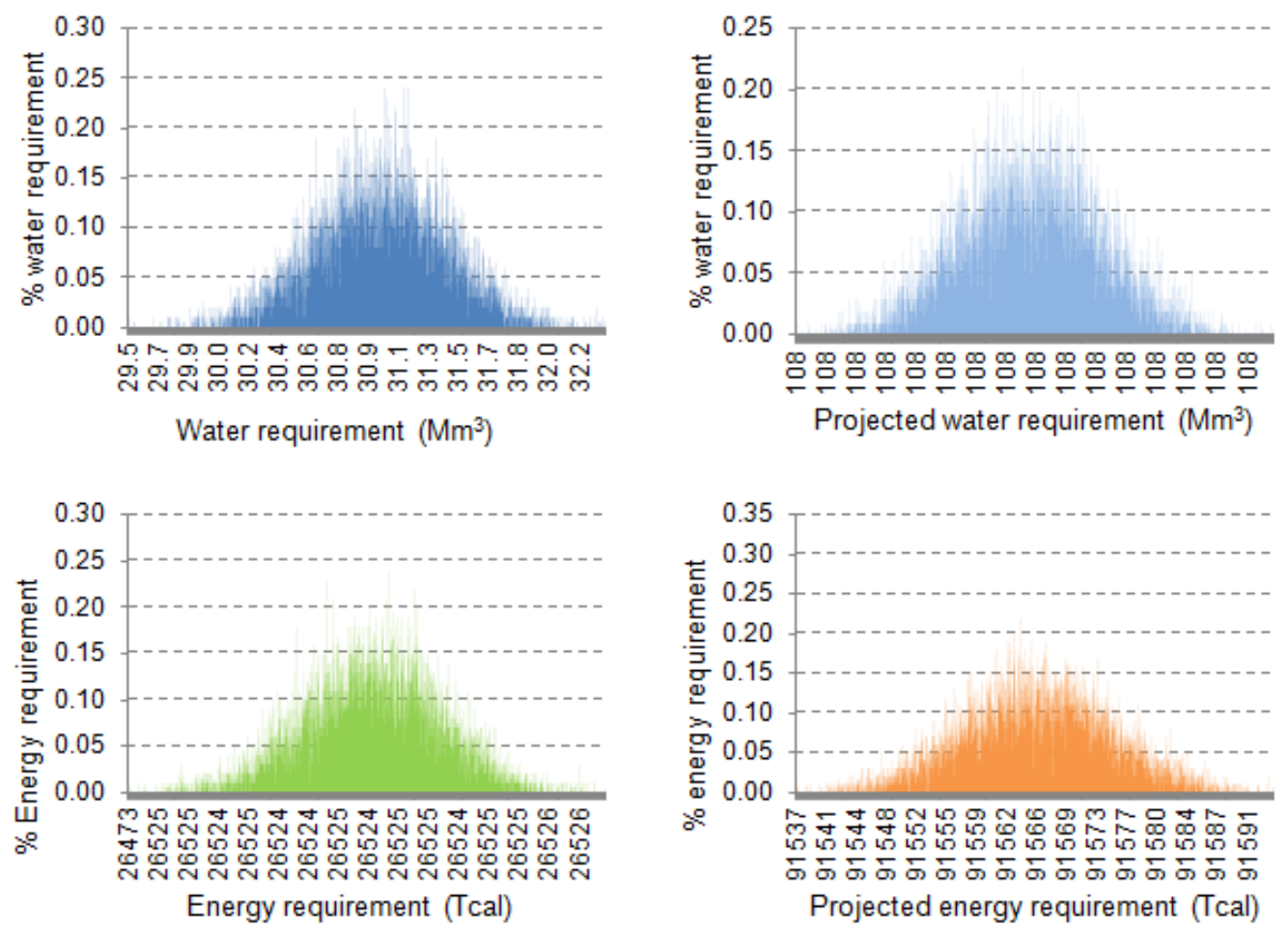

Figure 3: Status of water and food energy requirements in Tanzania for 2005 - 2050

\subsection{Virtual water transfers of crop and animal products}

Tanzania had a positive virtual water balance, with a net virtual water import of $9.1 \mathrm{Mm}^{3}$ in 2005. The gross virtual water import was $107.8 \mathrm{Mm}^{3}$ with most virtual water import from oil seed and other crops while gross virtual water export was about $61.71 \mathrm{Mm}^{3}$ with more exports on fruits and nuts (Table 1).

Freshwater intensity of crop, animal and their derived products consumption is $18 \mathrm{~kg} / \mathrm{m}^{3}$ for cereals, $10 \mathrm{~kg} / \mathrm{m}^{3}$ for vegetables and melons, $4 \mathrm{~kg} / \mathrm{m}^{3}$ for fruits and nuts, $1 \mathrm{~kg} / \mathrm{m}^{3}$ for oil seed and crops, $3 \mathrm{~kg} / \mathrm{m}^{3}$ for beverage and other crops, $3 \mathrm{~kg} / \mathrm{m}^{3}$ for meat, eggs and milk and no blue water use by root/tuber crops.

Table 1: Average Virtual Water Transfer of Crops and Animal Products in Tanzania

\begin{tabular}{|c|c|c|c|c|c|}
\hline Product class & $\begin{array}{l}\text { Produc } \\
\text { Import }\end{array}$ & $\begin{array}{l}\text { S (MKg) } \\
\text { Export }\end{array}$ & $\begin{array}{l}\text { Virtual n } \\
\text { Import }\end{array}$ & $\begin{array}{l}\text { ter }\left(\mathrm{Mm}^{3}\right) \\
\text { Export }\end{array}$ & $\begin{array}{l}\text { Net-virtual water } \\
\text { import }\left(\mathrm{Mm}^{3}\right)\end{array}$ \\
\hline Cereals & 650 & 129 & 34.32 & 7.41 & 26.90 \\
\hline Vegetables \& melons & 5 & 8 & 0.38 & 0.56 & -0.18 \\
\hline Fruits \& nuts & 19 & 34 & 1.90 & 76.4 & -74.49 \\
\hline Oil seed \& other crops & 267 & 46 & 61.71 & 2.83 & 58.87 \\
\hline Root/tuber crops & 0 & 5 & 0.0 & 0.08 & -0.08 \\
\hline Beverage \& other crops & 13 & 86 & 3.31 & 10.95 & -7.64 \\
\hline Meat, eggs \& milk & 20 & 2 & 6.26 & 0.63 & 5.62 \\
\hline
\end{tabular}




\subsection{Water footprint and energy value scenario analysis}

Modeling scenarios helps to capture the relationship between food nutrition values and freshwater requirements to produce specific crop and animal products which have big contributions to country's status of water scarcity. Significant variations in freshwater saving and energy supply were obtained through changes in consumption pattern and virtual water import/export strategy (Figure 4).

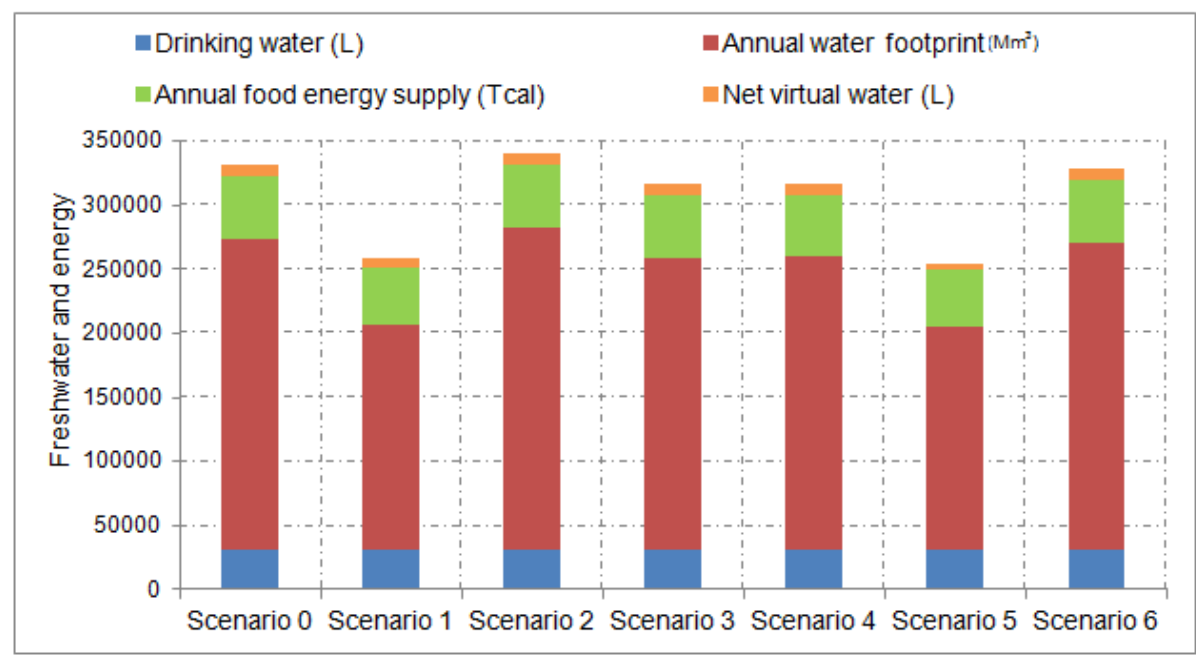

Figure 4: Scenario analysis to model freshwater change caused by variations in consumption pattern

Dietary change from calorie and meat intensive to standardized consumption demonstrated possible annual freshwater and food energy saving of about $1605 \mathrm{Mm}^{3}$ and 6630Tcal respectively (Table 2 ).

Table 2. Summary of the Scenario Analysis Results

\begin{tabular}{|c|c|c|c|c|}
\hline No. & $\begin{array}{l}\text { Description of the scenario } \\
\text { performance }\end{array}$ & $\begin{array}{l}\text { Water } \\
\text { saving } \\
\left(\mathrm{Mm}^{3}\right)\end{array}$ & $\begin{array}{c}\text { Energy } \\
\text { saving (Tcal) }\end{array}$ & $\begin{array}{c}\text { Net virtual } \\
\text { water transfer } \\
\left(\mathrm{Mm}^{3}\right)\end{array}$ \\
\hline 0 & $\begin{array}{l}\text { The actual food consumption baseline } \\
\text { for comparison of freshwater change. }\end{array}$ & baseline & baseline & baseline \\
\hline 1 & $\begin{array}{l}25 \% \text { replacement of animal products } \\
\text { consumption with vegetable products. }\end{array}$ & 679 & 3605 & 9.0 \\
\hline 2 & $\begin{array}{l}50 \% \text { replacement of bovine meat } \\
\text { consumption with poultry products. }\end{array}$ & $89^{*}$ & 247 & 7.5 \\
\hline 3 & $\begin{array}{l}50 \% \text { replacement of bovine meat with } \\
\text { vegetable and poultry products } \\
\text { consumption. }\end{array}$ & 154 & $189^{*}$ & 9.2 \\
\hline 4 & $\begin{array}{l}50 \% \text { replacement of meat consumption } \\
\text { with vegetable products. }\end{array}$ & 144 & 63 & 9.1 \\
\hline 5 & $\begin{array}{l}100 \% \text { replacement of animal products } \\
\text { consumption with vegetable products. }\end{array}$ & 688 & 3506 & 3.8 \\
\hline 6 & $\begin{array}{l}25 \% \text { replacement of wheat and rice } \\
\text { consumption with fruits. }\end{array}$ & 28 & $602^{*}$ & 9.0 \\
\hline
\end{tabular}




\section{DISCUSSION}

Understanding the connection between freshwater and energy content of food consumption is essential for sustainable water resources management. Comparing blue water footprint with gray and green water footprint, green water of crop and animal products consumption is the greatest but no significant competition to its uses. The absolute increase in the consumption of the products will change freshwater scarcity due to increased blue water requirements for the agriculture.

With consideration of the energy intensity of food class, more emphasis should be placed on consumption of products with high energy yields including root/tuber crops $\left(79365 \mathrm{kcal} / \mathrm{m}^{3}\right)$, cereals $\left(28055 \mathrm{kcal} / \mathrm{m}^{3}\right)$, oil seed crops $\left(21149 \mathrm{kcal} / \mathrm{m}^{3}\right)$ and discourage excessive consumption of meat, eggs and milk $\left(6973 \mathrm{kcal} / \mathrm{m}^{3}\right)$ which has intensive water requirements with low energy yield (Figure 2). The same strategy was proposed by Cazcarro and Chóliz (2012) to reduce blue water requirements for agriculture production.

The observed changes in consumption pattern of crop and animal products in Tanzania resulted into annual freshwater saving of $1605 \mathrm{Mm}^{3}$ which is about 41.307 $\mathrm{m}^{3} /$ capita and greater than drinking water requirement; with energy saving of 6630 Tcal equivalent to $170 \mathrm{Mcal} / \mathrm{capita}$. Similar results with freshwater saving achieved (RENAULT; WALLENDER, 2000) scenario analysis study case of California.

Government efforts to discourage consumption of animal products and more emphasis on vegetables are the best policy options for sustainable freshwater supply (Table 1). Change in consumption from bovine meat to poultry products results into increased water requirement for the food energy which is to be discouraged. While increasing consumption of fruits to replace rice has significant freshwater saving with conservation of the food energy needed. This signifies household's dietary shift in Tanzania provides an opportunity for freshwater scarcity reduction with adequate supply of food.

Tanzania similar to other countries of the world alleviates freshwater scarcity through virtual water transfer of crop and animal products. There is partial implementation of virtual water strategy indicated by importation of both water intensive animal products $\left(3 \mathrm{~kg} / \mathrm{m}^{3}\right)$ and oil seed crops $\left(1 \mathrm{~kg} / \mathrm{m}^{3}\right)$ and less water intensive cereal products $\left(18 \mathrm{~kg} / \mathrm{m}^{3}\right)$ to compensate freshwater and food energy 
scarcity. The importation of relatively water intensive products including fruit and nuts $\left(4 \mathrm{~kg} / \mathrm{m}^{3}\right)$, beverage and other crops $\left(3 \mathrm{~kg} / \mathrm{m}^{3}\right)$ was observed, similar results with $\mathrm{Ma}$ et al., (2006) the case of China. The condition of freshwater scarcity and nutrients supply would be more severe in the absence of virtual water transfers within and outside Tanzania.

Moreover, predicted increase in water and energy requirement for healthy Tanzanian population for $\mathbf{2 0 5 0}$ will ultimately affect freshwater needed for various utilizations including agriculture, hydropower, domestic and industry. This indicates human population to be an essential variable to be controlled to sustainable water and food supply. The results comprehended with ESOMAR (2011) and Kinabo (2003) who argued economic development of the developing and developed countries to be accompanied with dietary change in consumption pattern to more meat than traditional food, which is currently observed in Tanzania compared to few years ago.

\section{CONCLUSION}

The association between freshwater and food energy content of crop and animal products consumption in Tanzania has been evaluated. The blue, green and gray water types are all vitally important for the adequate food energy supply though with varied contributions to environmental impacts caused by freshwater consumptive uses in which knowledge about blue water requirement is most important.

Population dietary change in consumption pattern from animal products towards consumption of vegetables and effective application of virtual water strategy via importation of freshwater intensive products and exportation of less water intensive products were observed to have significant freshwater saving ultimately leading into reduced water scarcity in Tanzania. This calls the need for immediate investigation of the concerned policies to exploit more benefits of the dietary shifts and practicing virtual water strategy in the country.

\section{REFERENCES}

BAYART, B. J.; BULLE, C.; DESCHĚNES, L.; MARGANI, M.; PFISTER, S.; VINCE, F.; KOEHLER, A. (2010) A framework for assessing off-stream freshwater use in LCA. Int. J. Life Cycle Assess, v. 15, n. 15, p. 439-453. 
BERGER, M.; WARSEN, J.; KRINKE, S.; BACH, V.; FINKBEINER, M. (2012) Water footprint of European cars: Potential impact of water consumption along automobile life cycles. Environ. Sci. Technol., v. 46, n. 7, p. 409-4099.

BOULAY, A. M.; BULLE, C.; BAYART, J. B.; DESCHENES, L.; MARGNI, M. (2011) Regional characterization of freshwater use in life cycle assessment: Modeling direct human health impacts. Environment Sci. Technol., v. 45, n. 20, p. 8948-8957.

CANALS, L. I. M.; CHENOWETH, J.; CHAPAGAIN, A.; ORR, S.; ANTÓN, A.; CLIFT, R. (2009) Assessing freshwater use impacts in LCA: Part l-inventory modeling and characterization factors for the main impact pathways. International Journal Life Cycle Assess, v. 14, n. 1, p. 28-42.

CAZCARRO, I.; DUARTE, R.; CHÓLIZ, S. J. (2012) Water flows in the Spanish economy: Agri-food sectors, trade and households diets in an input-output framework. Environ. Sci. Technol., v. 46, n. 12, p. 6530-6538.

CHICO, D.; ALDAYA, M. M.; GARRIDO, A. (2013) A water footprint assessment of a pair of jeans: the influence of agricultural policies on the sustainability of consumer products. Journal of Cleaner Production v57, p238-248.

CHIU, W. Y.; WU, M. (2012) Assessing county level water footprints of different cellulosic biofuel feedstock pathways. Environ. Sci. Technol., v. 46, n. 16, p. 91559162.

CLEVELAND, A. D.; RADKA, N. C.; MÜLLER, M. N.; WATSON, D. T.; REKSTEIN, J. N.; WRIGHT, M. V. H.; HOLLINGSHEAD, E. S. (2011) Effect of localizing fruit and vegetable consumption on greenhouse gas emissions and nutrition, Santa Barbara County. Environ. Sci. Technol., v. 45, n. 10, p. 4555-4562.

ESOMAR (2011) Grow campaign global opinion research final topline report. Oxfam International (OXFAM), Hong Kong.

FAO (2001) Human energy requirements: Food and nutrition technical reports series no.1. Reports of joint FAO/WHO/UNU Expert Consultation, Rome.

FAO (2006) Livestock's long shadow environmental issues and options. Food and Agriculture Organization of the United Nations, Rome.

FAO (2012) Food balance sheets FAOSTAT global database. Food and Agriculture Organization of the United Nations, Rome.

GAN, J.; SMITH, T. C.; LANGEVELD, A. W. J. (2012) Effects of considering greenhouse gas consequences on fertilizer use in loblolly pine plantations. Journal Environment Management, v. 113, p. 383-389.

GLEICK, H. P. (1996) Basic Water Requirements for Human Activities: Meeting Basic Needs. Water Int., v. 21, n. 2, p. 83-92.

HELLER, C. M.; KEOLEIAN, A. G.; WILLETT, C. W. (2013) Toward a life cyclebased, diet-level framework for food environmental impact and nutritional quality assessment: A critical review. Environ. Sci. Technol., v. 47, p. 12632-12647.

HELLER, C. M; KEOLEIAN, A. G. (2011) Exploring a water/energy trade-offs in regional sourcing of livestock feed crops. Environ. Sci. Technol., v. 45, n. 24, p. 10619-10626. 
HOEKSTRA, A. Y.; CHAPAGAIN, A. K.; ALDAYA, M. M.; MEKONNEN, M. M. (2009) Water footprint manual: State of the art water footprint network: Enschede, the Netherlands.

HOEKSTRA, Y. A; MEKONNEN, M. M. (2011) The Water Footprint of Humanity. PNAS, v. 109, n. 9, p. 3232-3237.

JIAO, W.; MIN, Q.; CHENG, S.; LI, W. (2013). The waste absorption footprint (WAF): A methodological note on footprint calculations. Ecological Indicators, v. 34, p. 356360.

KINABO, J. (2003) Globalization of food systems: Impacts on food security and nutrition. FAO, Rome.

KOEHLER, A. (2008) Water use in LCA: Managing the planet's freshwater resources. Int. J. Life Cycle Assess. V. 13, n. 6, p. 451-455.

LAM, H-M.; REMAIS, J.; FUNG, M-C.; XU, L.; SUN, S-M. S. (2013) Food supply and food safety issues in China. LANCET, v. 381, n. 9882, p. 2044-2053.

LIU, S.; CROSSMAN, D. N.; NOLAN, M.; GHIRMAY, H. (2013) Bringing ecosystem services into integrated water resources management. Journal of Environmental Management, v. 129, p. 92-102.

MA, J.; HOEKSTRA, Y. A.; WANG, H.; CHAPAGAIN, K. A.; WANG, D. (2006) Virtual versus Real Water Transfers within China. Phil. Trans. R. Soc. B., v. 361, n. 1469, p. 835-842.

MAKURIRA, H.; SAVERIJE, H. H. G.; UHLENBROOK, S. (2009) Investigating water balance on farm techniques for improving crop productivity in rainfed systems: A case Study of Makanya Catchment Tanzania. Phys. Chem. Earth, v. 34, n. 1-2, p. 93-98.

MEKONNEN, M. M.; HOEKSTRA, A. Y. (2010) The green, blue and grey water footprint of farm animals and animal products, value of water research report series no. 48, UNESCO-IHE, Delf, the Netherlands.

MEKONNEN, M. M.; HOEKSTRA, Y. A., BECHT, R. (2012) Mitigating the water footprint of export cut flowers from the Lake Naivasha basin, Kenya Water Resour Manage 2012, v. 26, n. 13, p. 3725-3742.

MOE, L. C.; RHEINGANS, D. R. (2006) Global challenges in water, sanitation and health. Journal of Water and Health, v. 4, n. 1, p. 41-57.

MUELLER, D. N.; GERBER, S. J.; JOHNSTON, M.; RAY, K. D.; RAMANKUTTY, N.; FOLEY, A. J. (2012) Closing yield gaps through nutrient and water management. Nature, v. 490, p. 254-257.

MUTIRO, J.; MAKURIRA, H.; SENZANJE, A.; MUL, L. M. (2006) Water productivity analysis for smallholder rainfed systems: A case study of Makanya catchment Tanzania. Phys. Chem. Earth, v. 31, n. 15-16, p. 901-909.

NBS (2012) United Republic of Tanzania National sample census of agriculture small holder agriculture volume II, crop sector national report. The National Bureau of Statistics and the Office of the Chief Government Statistician, Zanzibar. 
NÚÑEZ, M.; PFISTER, S.; ROUX, P.; ANTÓN, A. (2013) Estimating water consumption of potential natural vegetation on global dry lands: Building an LCA framework for green water flows. Environ. Sci. Technol. v. 47, p. 12258-12265.

PACHPUTE, J. S. (2010) A Package of water management practices for sustainable growth and improved production of vegetable crop in labour and water scarce SubSahara Africa. Agric. Water Manage. v. 97, n. 9, p. 1251-1258.

PFISTER, S.; BAYER, P.; KOEHLER, A.; HELLWEG, S. (2011) Environmental impacts of water use in global crop production: Hotspots and trade-offs with land use. Environ. Sci. Technol., v. 45, n. 13, p. 5761-5768.

PFISTER, S.; KOEHLER, A.; HELLWEG, S. (2009) Assessing environmental impacts of freshwater consumption in life cycle assessment. Environ. Sci. Technol., v. 43, n. 11, p. 4098-4104.

POPKIN, M. B.; D'ANCI, E. K.; ROSENBERG, H. I. (2010) Water hydration and health. nutritional reviews, v. 68, n. 8, p. 439-458.

PREMA, R. (2013) Food and nutrition security: Challenges in the new millennium. The Indian journal of medical research, v. 138, n. 3, p. 373-82.

REEMTSMA, T.; ALDER, L.; BANASIAK, U. (2013). Emerging pesticide metabolites in groundwater and surface water as determined by the application of a multimethod for 150 pesticide metabolites. Water Research, v. 47, n. 553.

RENAULT, D.; WALLENDER, W. W. (2000) Nutrition water productivity and diets. Agric. Water Manage. v. 45, n. 3, p. 275-296.

RIDOUTT, B. G.; PfiSTER, S. (2010) Arevised approach to water footprinting to make transparent the impacts of consumption and production on global freshwater scarcity. Global Environ. Chang. V. 20, n. 1, p. 113-120.

RIDOUTT, G. B.; SANGUANSRI, P.; NOLAN, M.; MARKS, N. (2012) Meat consumption and water scarcity: Beware of generalizations. Journal of Cleaner Production, v. 28, p. 127-133.

ROY, B. S.; CHEN, L.; GIRVETZ, H. E.; MAURER, P. E.; MILLS, B. W.; GRIEB, M. T. (2012) Projecting water withdrawal and supply for future decades in the U.S under climate change scenarios. Environ. Sci. Technol., v. 46, n. 5, p. 2545-2556.

SAWKA, N. M.; CHEUVRONT, N. S.; CARTER, R. (2005) Human water needs. Nutritional Reviews, v. 63, n. 6, p. 30-39.

STOESSEL, F.; JURASKE, R.; PFISTER, S.; HELLWEG, S. (2012) Life cycle inventory and carbon and water footprint of fruits and vegetables: Application to a Swiss retailer. Environ. Sci. Technol., v. 46, n. 6, p. 3253-3262.

TUOMISTO, L. H., MATTOS, T. J. M. (2011) Environmental impact of cultured meat production. Environ. Sci. Technol., v. 45, n. 14, p. 6117-6123.

U.S. CENSUS BUREAU (2003) Tanzania population pyramid for 2005. U.S. census bureau, international database (Available at: http://www.nationmaster.com/country/tz/Age).

URT (1992) The food and nutrition policy of Tanzania. URT, United Republic of Tanzania, Ministry of Health. 
USDA (2011) Composition of foods raw, processed, prepared USDA national nutrient database for standard reference, release 24. Agricultural research service, Beltsville, Maryland (Available at: http://www.ars.usda.gov/nutrientdata).

VANHAM, D.; MEKONNEN, M. M.; HOEKSTRA, Y. A. (2013) The water footprint of the EU for different diets. Ecological Indicators, v. 32, p. 1-8.

WORLD HEALTH ORGANIZATION (2012) Water global analysis and assessment of sanitation and drinking water: The challenge of extending and sustaining services, GLAAS report. WHO Press, Switzerland.

WUTICH, A.; YORK, M. A.; BREWIS, A.; STOTTS, R.; ROBERTS, C. M. (2012) Shared cultural norms for justice in water institutions: Results from Fiji, Ecuador, Paraguay, New Zealand, and the U.S. J. Env. Manage. v. 113, p. 370-376.

YANG, Z.; MAO, X.; ZHAO, X.; CHEN, B. (2012) Ecological network analysis on global virtual water trade. Environ. Sci. Technol., v. 46, n. 3, p. 1796-1803.

ZHAO, X.; YANG, H.; YANG, Z.; CHEN, B.; QIN, Y. (2010) Applying the input-output method to account for water footprint and virtual water trade in the Haihe River basin.

Environ. Sci. Technol., v. 44, n. 23, p. 9150-9156. 